\title{
The cannabinoid system in the retrosplenial cortex modulates fear memory consolidation, reconsolidation, and extinction
}

\author{
Ricardo Marcelo Sachser, ${ }^{1,4}$ Ana Paula Crestani, ${ }^{2,4}$ Jorge Alberto Quillfeldt, ${ }^{2,4}$ \\ Tadeu Mello e Souza, ${ }^{3,4}$ and Lucas de Oliveira Alvares ${ }^{1,4}$ \\ ${ }^{1}$ Laboratório de Neurobiologia da Memória; ${ }^{2}$ Laboratório de Psicobiologia e Neurocomputação, Departamento de Biofísica, Instituto \\ de Biociências, Universidade Federal do Rio Grande do Sul, Porto Alegre 91501-970, Brazil; ${ }^{3}$ Departamento de Bioquímica, Instituto de \\ Ciências Básicas da Saúde, Universidade Federal do Rio Grande do Sul, Porto Alegre 90046-900, Brazil; ${ }^{4}$ Programa de Pós-Graduação \\ em Neurociências, Universidade Federal do Rio Grande do Sul, Porto Alegre 90046-900, Brazil
}

\begin{abstract}
Despite the fact that the cannabinoid receptor type 1(CBIR) plays a pivotal role in emotional memory processing in different regions of the brain, its function in the retrosplenial cortex (RSC) remains unknown. Here, using contextual fear conditioning in rats, we showed that a post-training intra-RSC infusion of the CBIR antagonist AM251 impaired, and the agonist CP55940 improved, long-term memory consolidation. Additionally, a post-reactivation infusion of AM251 enhanced memory reconsolidation, while CP55940 had the opposite effect. Finally, AM251 blocked extinction, whereas CP55940 facilitated it and maintained memory extinguished over time. Altogether, our data strongly suggest that the cannabinoid system of the RSC modulates emotional memory.
\end{abstract}

Memory consolidation is a time-dependent process through which newly acquired information is stored, even being able to becomestrengthened or weakened(Izquierdo et al. 1998; McGaugh 2000; Kandel 2001). During reconsolidation, memories may return to a transitory labile state sensitive to modifications (Nader et al. 2000; Haubrich et al. 2015), and it happens when the animal is reexposed briefly to the training environment. If this exposure takes longer in the absence of the unconditioned stimulus, extinction takes place, resulting in a new learning that is temporarily effective in inhibiting the conditioned response (Pavlov 1927; Quirk and Mueller 2008).

Endocannabinoids are retrograde messengers that control ion channel activity and neurotransmitter release (Katona et al. 1999, 2006; Ohno-Shosaku et al. 2001; Wilson and Nicoll 2001; Piomelli 2003), being critical to modulate both long-term potentiation (LTP) and long-term depression (LTD) (Wilson and Nicoll 2001; Brenowitz and Regehr 2005; Chevaleyre et al. 2006, 2007; Berghuis et al. 2007; Heifets and Castillo 2009; Katona and Freund 2012). In addition, CB1R-mediated signaling in both basolateral amygdala and dorsal hippocampus directly interacts with glucocorticoid receptors, indicating that these interactions are necessary for arousing-related experiences (Campolongo et al. 2009; Hill and McEwen 2009; Hill et al. 2010; De Oliveira Alvares et al. 2010).

The human posterior cingulate cortex (PCC) is involved in emotion processing (Maddock 1999), prospective thinking, and in memorizing spatial and autobiographical information (Vann et al. 2009). The PCC has no counterpart to Brodmann areas (BA) 23 and 31 in the rat brain. Therefore, in the rat, the entire region is called the retrosplenial cortex (RSC), which is, in humans, designated only to the most caudal, not the neocortical, part of PCC (BA 29 and 30) (Maddock 1999). The rat RSC is a very integrative area, since (a) it intermediates many signals between the hip-

\section{Corresponding author: lucas.alvares@ufrgs.br}

Article is online at http://www.learnmem.org/cgi/doi/10.1101/lm.039891. 115 . pocampal formation, thalamic regions, and the prefrontal cortex, (b) receiving information from neocortical visual, auditory, and motor areas (Hedberg and Stanton 1995; Maddock 1999; Vann et al. 2009). For these reasons, it is not surprising that it is involved in emotional and spatial memory processing in both humans and rodents (Maddock 1999; Mello e Souza et al. 1999; Souza et al. 2002; Vogt et al. 2000; Vann et al. 2009; Corcoran et al. 2011; Katche et al. 2013a,b; Czajkowski et al. 2014).

The resulting effects of local or systemic pharmacological manipulations of CB1R in different fear-related tasks in rodents is well described in the hippocampus (De Oliveira Alvares et al. 2005), basolateral amygdala (Marsicano et al. 2002; Lin et al. 2006; Campolongo et al. 2009), and prefrontal cortex (Morena et al. 2014), three brain structures associated with the modulation of long-term memories. Also, previous findings from our group have shown that, at cellular and behavioral levels, blocking CB1R with the selective antagonist AM251 (a) inhibits the induction of hippocampal LTP, and (b) cause retrograde amnesia if applied immediately post-training in different Pavlovian paradigms (De Oliveira Alvares et al. 2005, 2006, 2008a,b).

Despite the fact that in the last decades many important contributions have provided a comprehensive understanding about the specific functions of endocannabinoids on memory-related plasticity throughout the brain, the role of the cannabinoid system in the rodent RSC on memory paradigms was unknown. In the present study we explored whether memory consolidation, reconsolidation, and extinction were dependent on cannabinoidmediated signaling in the RSC.

Male Wistar rats (3 mo old, 300-350 g) acquired from Centro de Reprodução e Experimentação de Animais de Laboratório of the

\footnotetext{
C 2015 Sachser et al. This article is distributed exclusively by Cold Spring Harbor Laboratory Press for the first 12 months after the full-issue publication date (see http://learnmem.cshlp.org/site/misc/terms.xhtml). After 12 months, it is available under a Creative Commons License (AttributionNonCommercial 4.0 International), as described at http://creativecommons. org/licenses/by-nc/4.0/.
} 
Universidade Federal do Rio Grande do Sul were implanted bilaterally with guide cannulae aimed $1 \mathrm{~mm}$ above the RSC (AP $-5.8 \mathrm{~mm}$, $\mathrm{ML} \pm 0.6 \mathrm{~mm}$, and DV $-1.2 \mathrm{~mm}$ taken from dura, Fig. $1 \mathrm{~A})$, the same as reported previously by Mello e Souza (1999). Animals were infused intra-RSC with the cannabinoid agonist CP55940 $(5 \mu \mathrm{g} / \mu \mathrm{L})$, the selective antagonist of CB1R AM251 $(11 \mu \mathrm{g} / \mu \mathrm{L})$, or their vehicles (PBS containing DMSO 8\%) at different time points, depending on the experiment. The drug concentrations were chosen accordingly to previous results (De Oliveira Alvares et al. 2005) and unpublished data from our group. All drugs were infused at a slow rate of $20 \mu \mathrm{L} / \mathrm{h}$ with the dose adjusted at $0.5 \mu \mathrm{L} /$ side. The conditioning chamber consisted of an illuminated Plexigas box $\left(25 \times 25 \times 25 \mathrm{~cm}^{3}\right)$ with a metallic grid floor of parallel 1-cm caliber stainless steel bars spaced 1-cm apart. During training sessions, rats were carefully placed in the chamber for $3 \mathrm{~min}$ and received two mild footshocks $(0.5 \mathrm{~mA}, 2 \mathrm{sec})$ separated by a 30 -sec interval; after that, they remained for an additional $30 \mathrm{sec}$ before being placed back into their home cages. For training, reactivation, and test sessions, we used a 4-min reexposure, except during the extinction protocol, where a 30-min reexposure was used. After each rat, the chamber was cleaned with a paper soaked with $70 \%$ ethanol solution. Freezing levels (the absence of movement except for respiration) was measured by a trained researcher blind to experimental conditions. Data were analyzed by indepen-

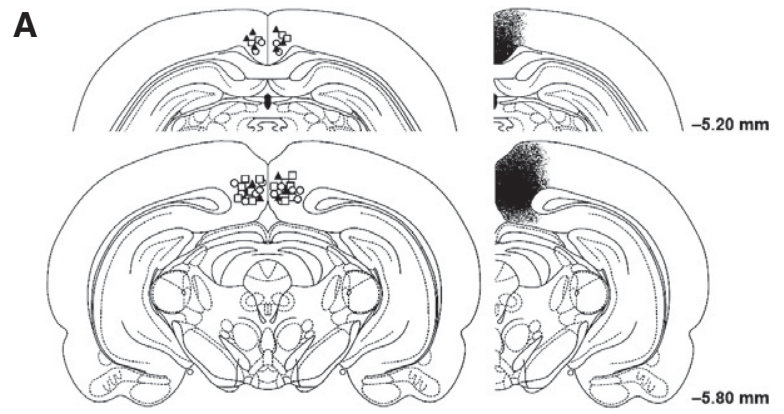

B

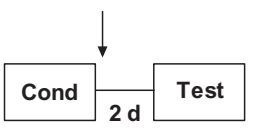

C

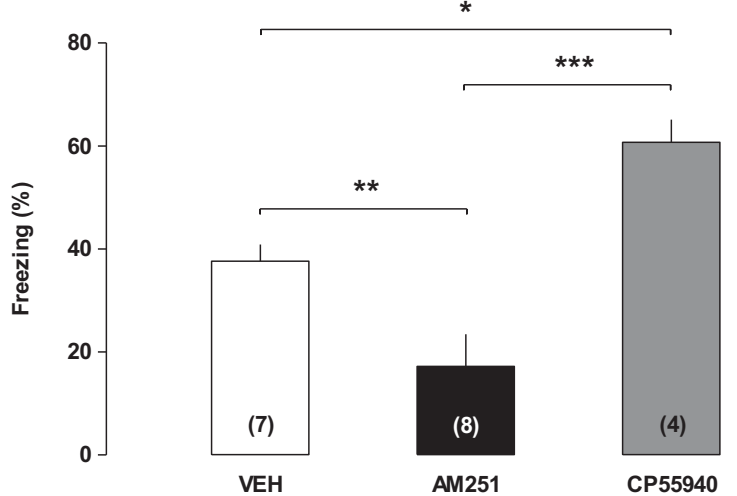

Figure 1. Contextual fear long-term memory consolidation requires cannabinoid activation in the RSC. (A) Illustration of the cannulae placement and drug diffusion in the retrosplenial cortex. (B) Experimental design. (C) Effects of post-training intra-RSC infusions of AM251, CP55940 or their vehicle on percentage of freezing time during a test session performed $2 \mathrm{~d}$ after conditioning, indicating that contextual fear long-term memory consolidation is mediated through cannabinoid receptors in the retrosplenial cortex. $\left(^{*}\right) P<0.05,\left({ }^{* *}\right) P<0.01$, and (***) $P<0.001$. Arrow indicates infusion time. dent $t$-test, one-way or repeated-measures ANOVA, followed by Newman-Keuls (NK) post hoc test whenever necessary. $P<0.05$ indicates statistical significance. Verification of cannula placement was made from coronal sections of the RSC using a vibratome and standard histological techniques (details in Mello e Souza et al. 1999). Only rats with correct cannulae placement were considered in the final statistical analysis.

The RSC is divided into two parts, granular and dysgranular, which are different in their inputs and outputs (Wyss and Sripanidkulchai 1984; Vann et al. 2009). In previous studies, the coordinates were slightly more ventral, infusions into which were more restricted to the granular cortex (Mello e Souza et al. 1999; Souza et al. 2002). In the present study, both parts were reached by our infusions, but not neighboring regions, such as the hippocampal formation (Fig. 1A). Therefore, we can analyze our results by considering the interaction of the RSC as a whole with other brain structures.

It is well known that the RSC interacts with the hippocampal formation through robust reciprocal connections with the subiculum, presubiculum, and parasubiculum (Vann et al. 2009). The RSC also projects to the entorhinal cortex (Wyss and Van Groen 1992), another region functionally linked to the hippocampus. Previous results have already shown its involvement in emotional (Mello e Souza et al. 1999; Souza et al. 2002; Corcoran et al. 2011; Katche et al. 2013a,b) and spatial memory modulation (Czajkowski et al. 2014). This is the first study to show that cannabinoid receptors in the RSC may modulate aversive memory. It is very difficult to not link this result to the fact that the RSC strongly interacts with the hippocampal formation and several other memory-related structures (Hedberg and Stanton 1995; Maddock 1999; Vann et al. 2009). In fact, the RSC has a strategic position intermediating signals between the hippocampal formation and neocortex (Cooper and Mizumori 2001; Vann et al. 2009). Nonetheless, further studies are necessary to clarify how these interactions are affected by the procedures carried out in the present study. It is worth to point out that there are CB1R in the RSC (Tsou et al. 1998; Moldrich and Wenger 2000).

In order to explore the involvement of CB1R activity in the RSC on contextual fear long-term consolidation, rats were randomly assigned to three groups and, immediately post-training, infused intra-RSC with AM251, CP55940, or its vehicle. Freezing behavior was assessed $2 \mathrm{~d}$ later during a drug-free 4-min test session. As shown in Figure 1B, there was a significant difference between groups as revealed by one-way ANOVA $\left(F_{(2,16)}=14.54 ; P=\right.$ 0.0003). CP55940- and AM251-treated animals showed higher and lower freezing levels than controls, respectively (NK test, $P=0.0098$ and 0.0196 , respectively). These results strongly suggest that the activation of the cannabinoid receptors in the RSC strengthens consolidation of contextual fear memory.

Memory consolidation is a time-dependent process through which newly acquired information is stored (Izquierdo et al. 1998; McGaugh 2000; Kandel 2001). RSC activity is strongly related to the consolidation and maintenance of spatial (Czajkowski et al. 2014) and aversive memories (Mello e Souza et al. 1999; Souza et al. 2002; Corcoran et al. 2011; Katche et al. 2013a,b). Our results strongly suggest that the cannabinoid receptors activation in the RSC improves contextual fear memory consolidation, since the agonist CP55940 increased freezing levels while the antagonist AM251 was amnestic. The same responses are found when cannabinoid drugs are infused into the hippocampus (De Oliveira Alvares et al. 2005, 2006). Therefore, both systems have a similar modulatory role in memory consolidation. However, the mechanisms underlying this modulation in both structures remain to be elucidated.

Next, we investigate the role of the cannabinoid system of the RSC on memory reconsolidation (Fig. 2). To do this, rats 
A

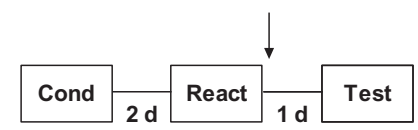

B

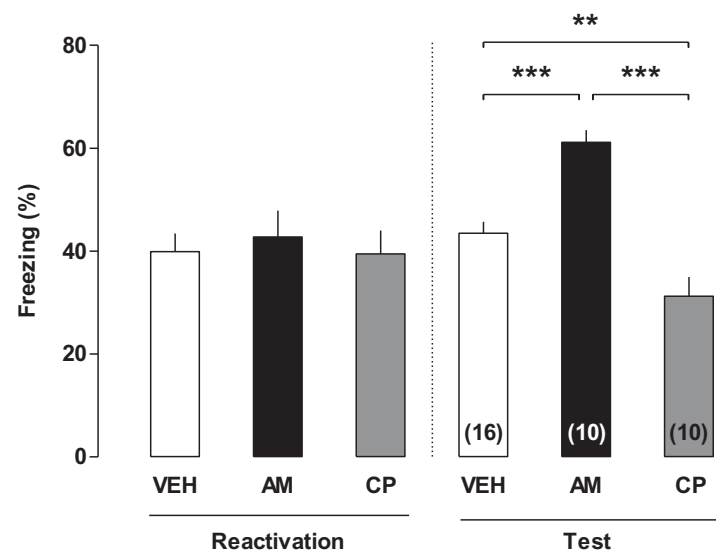

Figure 2. CB1R-dependent signaling modulates contextual fear memory reconsolidation in the RSC. ( $A$ ) Experimental design. (B) Effects of post-reactivation intra-RSC infusions of AM251, CP55940 or their vehicle on the percentage of freezing time evaluated $1 \mathrm{~d}$ later (right panel). Left panel shows the percent of freezing time during the reactivation session. (**) $P<0.01$ and $\left({ }^{* * *}\right) P<0.001$. Arrow indicates infusion time.

were briefly reexposed to the original context $2 \mathrm{~d}$ later to reactivate the established long-term memory, and immediately postreactivation, each subject was bilaterally infused with CP55940, AM251, or its vehicle. A drug-free 4-min test for memory retention was carried out $24 \mathrm{~h}$ after reactivation. There was a between-group difference in the test session (one-way ANOVA, $F_{(2,29)}=17.61 ; P<$ 0.0001 ), but not in the reactivation session (one-way ANOVA, $\left.F_{(2,29)}=0.89 ; P=0.4205\right)$. Testing freezing levels were higher in the AM251-treated animals and lower in the CP55940-treated group relative to controls $(P=0.0001$ and 0.0080 , respectively; NK post hoc test), indicating a facilitatory and a disruptive effect on reconsolidation, respectively. Altogether, these results show that CB1Rs negatively modulate contextual fear memory reconsolidation.

During reconsolidation, memories can return to a transitory labile state that is sensitive to modifications (Nader et al. 2000; Haubrich et al. 2015). Since we found that AM251 increased freezing levels while the CP55940 was amnestic when administered immediately after memory reactivation, we suggest that RSC-CB1Rs inhibit contextual fear memory reconsolidation. Indeed, when administered into the hippocampus, AM251 also enhances the freezing response in this paradigm (De Oliveira Alvares et al. 2008b). Additionally, when infused into the amygdala, the cannabinoid receptor agonist WIN blocks fear memory reconsolidation (Lin et al. 2006), the same effect found here using CP55940. All of these results indicate that endocannabinoids exert their actions with similar patterns in different brain regions. One possible mechanism is that CB1Rs act on the inhibitory neurotransmission, as observed in the amygdala (Ratano et al. 2014). However, the mechanisms underlying the effects of the cannabinoid receptors in the RSC on memory reconsolidation remain to be clarified in further studies. It is possible that the memory effects reported here are mediated by CB1R localized on both inhibitory interneurons and glutamatergic axon terminals. Nevertheless, we cannot dissect the role of CB1R in different neuronal populations with our pharmacological tools. It is also important to mention that these opposite effects on memory consolidation and reconsolidation also occur when glucocorticoid receptors are activated (Wang et al. 2008; De Oliveira Alvares et al. 2010). Interestingly, stress triggers an increase of endocannabinoids in the central nervous system (Hohmann et al. 2005), and this might happen in the RSC during memory consolidation and reconsolidation.

In order to evaluate the involvement of the cannabinoid system upon memory extinction, fear-conditioned rats were bilaterally infused intra-RSC $20 \mathrm{~min}$ before the extinction session. Freezing levels during extinction session and retention tests are shown in Figure 3. In the first and last 4 min of the 30-min extinction session, there were differences indicated by repeatedmeasures ANOVA (main group effect, $F_{(2,24)}=8.01 ; P=0.0022$;
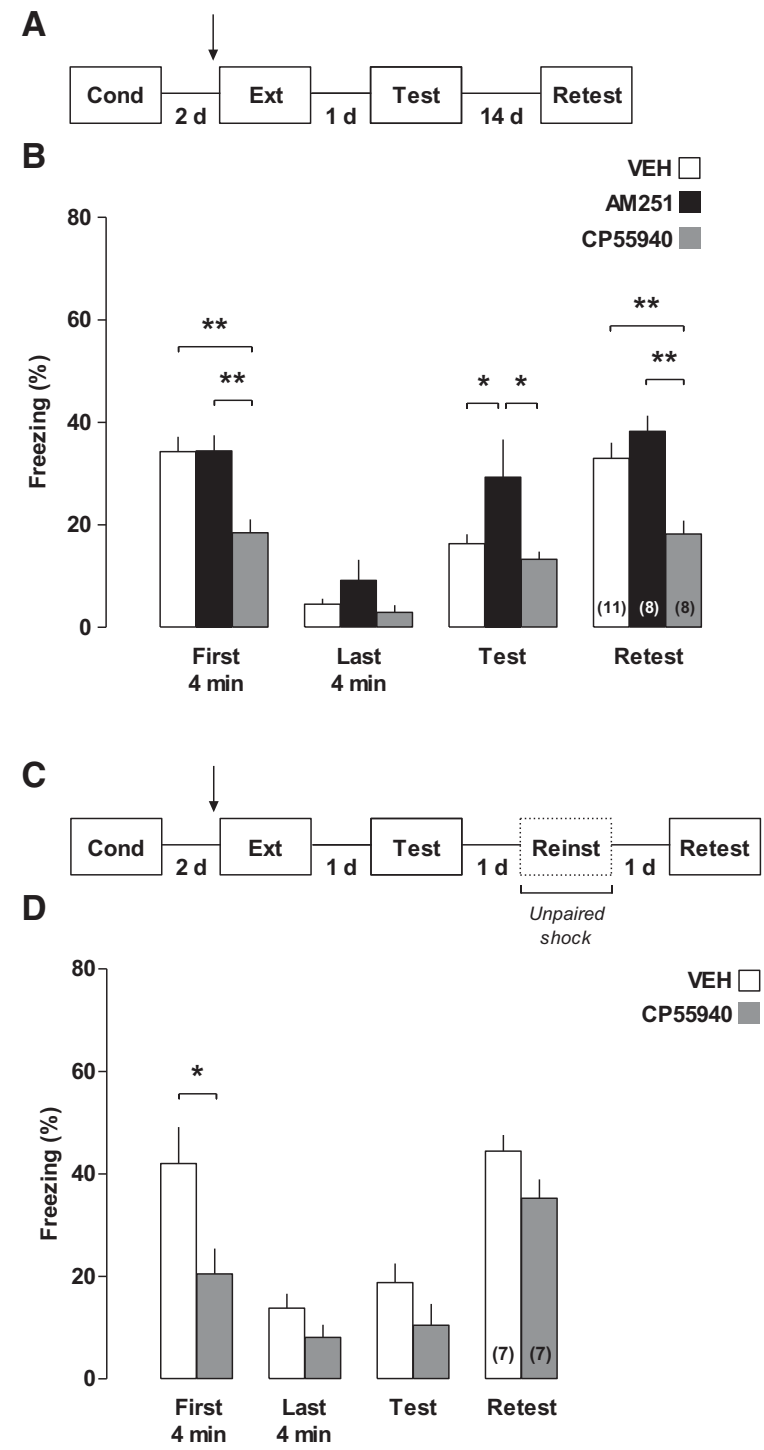

Figure 3. Involvement of the cannabinoid system in the RSC during contextual fear memory extinction. $(A, C)$ Different behavioral procedures were used to assess memory extinction. (B) Fear-conditioned rats were bilaterally infused into the RSC with cannabinoid drugs 20 min before extinction training. Tests 1 and 2 were carried out 1 and 14 d later, respectively. CP55940 increased extinction and maintained fear response extinguished over time, whereas AM251 impaired memory extinction. (D) Fear reinstatement was observed in rats infused intra-RSC with CP55940 or their vehicle 20 min before extinction training. $\left(^{*}\right) P<0.05$ and $\left(^{* *}\right)$ $P<0.01$. Arrow indicates infusion time. 
main time effect, $F_{(1,24)}=134.00, P<0.0001$; two-way interaction, $\left.F_{(2,24)}=4.37, P=0.0242\right)$. CP55940-treated group showed lower freezing levels than controls and AM251-treated animals in both periods combined (NK post hoc test, $P<0.01$ ), as well as in the beginning of the session alone (NK post hoc test, $P<$ 0.001). This indicates that (a) CP55940 impairs memory expression (alternatively, it might also indicate that CP55940 increases short-term extinction or acute fear adaptation), and (b) all groups showed lower freezing levels in the end of the session $(P<0.01$, NK post hoc test), indicating that extinction occurred in all groups.

In the first drug-free test session carried out $24 \mathrm{~h}$ after the extinction training, there was a between-group difference (one-way ANOVA $\left.F_{(2,24)}=4.38 ; P=0.0239\right)$. AM251-treated group showed higher freezing levels than controls and CP55940-treated animals $(P<0.05$, NK post hoc test), indicating that AM251 impairs extinction. In the second test that was carried out 2 wk later and was used to assess spontaneous recovery, there was also a between-group difference (one-way ANOVA, $F_{(2,19)}=12$.03; $P<$ $0.0004)$. CP55940-treated animals maintained the lower freezing levels presented in the first test compared with controls and AM251-treated animals $(P<0.01$, NK post hoc test). This indicates that the agonist CP55940 prevents spontaneous recovery (i.e., maintaining memory extinguished over time).

One could argue that the absence of spontaneous recovery in the CP55940 may indicate that it impaired reconsolidation rather than extinction. To rule out this possibility, another cohort of animals was fear-conditioned and exposed to a 30-min extinction session. Then, animals were bilaterally infused intra-RSC with either CP55940 or vehicle 20 min before the extinction session. One day later, they were subjected to reinstatement (a single 0.5-mA footshock in a different environment, according to Haubrich et al. 2015). In the following day, they were tested (Fig. 3D).

In the first and last $4 \mathrm{~min}$ of the 30-min extinction session, there were differences indicated by repeated-measures ANOVA (main group effect, $F_{(1,11)}=6.306 ; P=0.028$; main time effect, $F_{(1,11)}=36.11, P<0.0001$; interaction, $\left.F_{(1,11)}=4.89, P=0.049\right)$, as follows: (a) CP55940-treated animals showed lower freezing levels than controls in both periods combined (NK post hoc test, $P=0.02$ ), as well as in the beginning of the session alone (NK post hoc test, $P=0.021$ ). No difference was shown in the first test $\left(t_{(11)}=1.466 ; P=0.17\right)$ and in the reinstatement test $\left(t_{(11)}=\right.$ $1.85 ; P=0.09$; independent $t$-test). Thus, the recovery of fear memory after reinstatement indicates that the effects followed a 30 -min reexposure session is mediated by memory extinction. Taken together, our data showed that CB1R-mediated signaling in the RSC plays an important role in fear memory extinction.

The extinction of a CS-US association is a form of new learning that inhibits conditioned fear responses (Pavlov 1927; Quirk and Mueller 2008). However, extinction may fail to permanently suppress fear memory due to reinstatement, spontaneous recovery, and rapid reacquisition (Bouton et al. 2006). It is wellestablished that CB1Rs play a pivotal role in memory extinction, at least in the amygdala and the hippocampus (Marsicano et al. 2002; Chhatwal et al. 2005; Pamplona et al. 2006; Lutz 2007; De Oliveira Alvares et al. 2008b). Recently, two important studies showed the involvement of the RSC in memory extinction (Corcoran et al. 2013; Kwapis et al. 2014). Here, we have shown that the cannabinoid system of the RSC is strongly engaged in this process. When the CB1R-mediated activity was blocked, consolidation of extinction was impaired, since the AM251-treated group showed higher freezing levels when tested $24 \mathrm{~h}$ later, but showed similar freezing levels during extinction session. Fourteen days later, when spontaneous recovery was evaluated, CP55940-treated group prevented this response by maintaining memory extinguished. Therefore, the consolidation of extinction requires cannabinoid receptor activation in the RSC.

In humans, trauma-related stimuli cause a higher activation of the RSC in patients diagnosed with post-traumatic stress disorder (PTSD) than in controls (Sartory et al. 2013). Therefore, based on our results, the requirement of the CB1R-dependent activity in the RSC during emotional memory processing may be taken into account when searching putative treatments for PTSD or other incapacitating psychopathologies in which aversive memories are maladaptive.

In summary, the present study shows for the first time that the cannabinoid system in the RSC modulates contextual fear memory consolidation, reconsolidation, and extinction. This modulation is the same of that promoted by hippocampal CB1Rs, suggesting that there may be a general modulatory function of the endocannabinoid system in emotional memory processing.

\section{Acknowledgments}

We acknowledge CAPES (Ministério da Educação, República Federativa do Brasil) for the financial support. We also thank Mrs Zelma Regina de Almeida for her kind technical assistance, and Josué Haubrich for their helpful comments and suggestions.

\section{References}

Berghuis P, Rajnicek AM, Morozov YM, Ross RA, Mulder J, Urbán GM, Monory K, Marsicano G, Matteoli M, Canty A, et al. 2007. Hardwiring the brain: endocannabinoids shape neuronal connectivity. Science 316: $1212-1216$.

Bouton ME, Westbrook RF, Corcoran KA, Maren S. 2006. Contextual and temporal modulation of extinction: behavioral and biological mechanisms. Biol Psychiatry 60: 352-360.

Brenowitz SD, Regehr WG. 2005. Associative short-term synaptic plasticity mediated by endocannabinoids. Neuron 45: 419-431.

Campolongo P, Roozendaal B, Trezza V, Hauer D, Schelling G, McGaugh JL, Cuomo V. 2009. Endocannabinoids in the rat basolateral amygdala enhance memory consolidation and enable glucocorticoid modulation of memory. Proc Natl Acad Sci 106: 4888-4893.

Chevaleyre V, Takahashi KA, Castillo PE. 2006. Endocannabinoidmediated synaptic plasticity in the CNS. Annu Rev Neurosci 29: $37-76$.

Chevaleyre V, Heifets BD, Kaeser PS, Südhof TC, Castillo PE. 2007. Endocannabinoid-mediated long-term plasticity requires cAMP/PKA signaling and RIM1 $\alpha$. Neuron 54: 801-812.

Chhatwal JP, Davis M, Maguschak KA, Ressler KJ. 2005. Enhancing cannabinoid neurotransmission augments the extinction of conditioned fear. Neuropsychopharmacology 30: 516-524.

Cooper BG, Mizumori SJ. 2001. Temporary inactivation of the retrosplenial cortex causes a transient reorganization of spatial coding in the hippocampus. J Neurosci 21: 3986-4001.

Corcoran KA, Donnan MD, Tronson NC, Guzmán YF, Gao C, Jovasevic V, Guedea AL, Radulovic J. 2011. NMDA receptors in retrosplenial cortex are necessary for retrieval of recent and remote context fear memory. $J$ Neurosci 31: 11655-11659.

Corcoran KA, Leaderbrand K, Radulovic J. 2013. Extinction of remotely acquired fear depends on an inhibitory NR2B/PKA pathway in the retrosplenial cortex. J Neurosci 33: 19492-19498.

Czajkowski R, Jayaprakash B, Wiltgen B, Rogerson T, Guzman-Karlsson MC, Barth AL, Trachtenberg JT, Silva AJ. 2014. Encoding and storage of spatial information in the retrosplenial cortex. Proc Natl Acad Sci 111: 8661-8666.

De Oliveira Alvares L, de Oliveira LF, Camboim C, Diehl F, Genro BP, Lanziotti VB, Quillfeldt JA. 2005. Amnestic effect of intrahippocampal AM251, a CB1-selective blocker, in the inhibitory avoidance, but not in the open field habituation task, in rats. Neurobiol Learn Mem 83: 119-124.

De Oliveira Alvares L, Pasqualini-Genro B, Vaz Breda R, Pedroso MF, Da Costa JC, Quillfeldt JA. 2006. AM251, a selective antagonist of the CB1 receptor, inhibits the induction of long-term potentiation and induces retrograde amnesia in rats. Brain Res 1075: 60-67.

De Oliveira Alvares L, Pasqualini Genro B, Diehl F, Molina VA, Quillfeldt JA. 2008a. Opposite action of hippocampal CB1 receptors in memory reconsolidation and extinction. Neuroscience 154: 1648-1655.

De Oliveira Alvares L, Genro BP, Diehl F, Quillfeldt JA. 2008b. Differential role of the hippocampal endocannabinoid system in the memory 
consolidation and retrieval mechanisms. Neurobiol Learn Mem 90: $1-9$.

De Oliveira Alvares L, Engelke DS, Diehl F, Scheffer-Teixeira R, Haubrich J, de Freitas Cassini L, Molina VA, Quillfeldt JA. 2010. Stress response recruits the hippocampal endocannabinoid system for the modulation of fear memory. Learn Mem 17: 202-209.

Haubrich J, Crestani AP, Cassini LF, Santana F, Sierra RO, de Oliveira Alvares L, Quillfeldt JA. 2015. Reconsolidation allows fear memory to be updated to a less aversive level through the incorporation of appetitive information. Neuropsychopharmacology 40: 315-326.

Hedberg TG, Stanton PK. 1995. Long-term potentiation and depression of synaptic transmission in rat posterior cingulate cortex. Brain Res 670: 181-196.

Heifets BD, Castillo PE. 2009. Endocannabinoid signaling and long-term synaptic plasticity. Annu Rev Physiol 71: 283-306.

Hill MN, McEwen BS. 2009. Endocannabinoids: the silent partner of glucocorticoids in the synapse. Proc Natl Acad Sci 106: 4579-4580.

Hill MN, Patel S, Campolongo P, Tasker JG, Wotjak CT, Bains JS. 2010. Functional interactions between stress and the endocannabinoid system: from synaptic signaling to behavioral output. J Neurosci 30: $14980-14986$.

Hohmann AG, Suplita RL, Bolton NM, Neely MH, Fegley D, Mangieri R, Krey JF, Walker JM, Holmes PV, Crystal JD, et al. 2005. An endocannabinoid mechanism for stress-induced analgesia. Nature 435: $1108-1112$.

Izquierdo I, Barros DM, Mello e Souza T, de Souza MM, Izquierdo LA, Medina JH. 1998. Mechanisms for memory types differ. Nature 393: 635-636.

Kandel ER. 2001. The molecular biology of memory storage: a dialogue between genes and synapses. Science 294: 1030-1038.

Katche C, Dorman G, Gonzalez C, Kramar CP, Slipczuk L, Rossato JI, Cammarota M, Medina JH. 2013a. On the role of retrosplenial cortex in long-lasting memory storage. Hippocampus 23: 295-302.

Katche C, Dorman G, Slipczuk L, Cammarota M, Medina JH. 2013b. Functional integrity of the retrosplenial cortex is essential for rapid consolidation and recall of fear memory. Learn Mem 20: 170-173.

Katona I, Freund TF. 2012. Multiple functions of endocannabinoid signaling in the brain. Annu Rev Neurosci 35: 529-558.

Katona I, Sperlágh B, Sik A, Käfalvi A, Vizi ES, Mackie K, Freund TF. 1999. Presynaptically located CB1 cannabinoid receptors regulate GABA release from axonal terminals of specific hippocampal interneurons. $J$ Neurosci 19: 4544-4558.

Katona I, Urbán GM, Wallace M, Ledent C, Jung KM, Piomelli D, Mackie K, Freund TF. 2006. Molecular composition of the endocannabinoid system at glutamatergic synapses. J Neurosci 26: 5628-5637.

Kwapis JL, Jarome TJ, Lee JL, Gilmartin MR, Helmstetter FJ. 2014. Extinguishing trace fear engages the retrosplenial cortex rather than the amygdala. Neurobiol Learn Mem 113: 41-54.

Lin HC, Mao SC, Gean PW. 2006. Effects of intra-amygdala infusion of CB1 receptor agonists on the reconsolidation of fear-potentiated startle. Learn Mem 13: 316-321.

Lutz B. 2007. The endocannabinoid system and extinction learning. Mol Neurobiol 36: 92-101.

Maddock RJ. 1999. The retrosplenial cortex and emotion: New insights from functional neuroimaging of the human brain. Trends Neurosci 22: 310-316.

Marsicano G, Wotjak CT, Azad SC, Bisogno T, Rammes G, Cascio MG, Hermann H, Tang J, Hofmann C, Zieglgänsberger W, et al. 2002. The endogenous cannabinoid system controls extinction of aversive memories. Nature 418: 530-534.

McGaugh JL. 2000. Memory-a century of consolidation. Science 287: $248-251$.
Mello e Souza T, Roesler R, Madruga M, de-Paris F, Quevedo J, Rodrigues C, Sant'Anna MK, Medina JH, Izquierdo I. 1999. Differential effects of post-training muscimol and AP5 infusions into different regions of the cingulate cortex on retention for inhibitory avoidance in rats. Neurobiol Learn Mem 72: 118-127.

Moldrich G, Wenger T. 2000. Localization of the CB1 cannabinoid receptor in the rat brain. An immunohistochemical study. Peptides 21: $1735-1742$.

Morena M, Roozendaal B, Trezza V, Ratano P, Peloso A, Hauer D, Atsak P, Trabace L, Cuomo V, McGaugh JL, et al. 2014. Endogenous cannabinoid release within prefrontal-limbic pathway affects memory consolidation of emotional training. Proc Natl Acad Sci 111: $18333-18338$

Nader K, Schafe GE, LeDoux JE. 2000. Fear memories require protein synthesis in the amygdala for reconsolidation after retrieval. Nature 406: $722-726$.

Ohno-Shosaku T, Maejima T, Kano M. 2001. Endogenous cannabinoids mediate retrograde signals from depolarized postsynaptic neurons to presynaptic terminals. Neuron 29: 729-738.

Pamplona FA, Prediger RD, Pandolfo P, Takahashi RN. 2006. The cannabinoid receptor agonist WIN 55,212-2 facilitates the extinction of contextual fear memory and spatial memory in rats. Psychopharmacology 188: 641-649.

Pavlov IP. 1927. Conditioned reflexes: an investigation of the physiological activity of the cerebral cortex. Oxford University Press, London.

Piomelli D. 2003. The molecular logic of endocannabinoid signaling. Nat Rev Neurosci 4: 873-884.

Quirk GJ, Mueller D. 2008. Neural mechanisms of extinction learning and retrieval. Neuropsychopharmacology 33: 56-72.

Ratano P, Everitt BJ, Milton AL. 2014. The CB1 receptor antagonist AM251 impairs reconsolidation of Pavlovian fear memory in the rat basolateral amygdala. Neuropsychopharmacology 39: 2529-2537.

Sartory G, Cwik J, Knuppertz H, Schürholt B, Lebens M, Seitz RJ, Schulze R. 2013. In search of the trauma memory: a meta-analysis of functional neuroimaging studies of symptom provocation in posttraumatic stress disorder (PTSD). PLoS One 8: e58150.

Souza MM, Mello e Souza T, Vinadé ER, Rodrigues C, Choi HK, Dedavid e Silva TL, Medina JH, Izquierdo I. 2002. Effects of posttraining treatments in the posterior cingulate cortex on short- and long-term memory for inhibitory avoidance in rats. Neurobiol Learn Mem 77: $202-210$.

Tsou K, Brown S, Sañudo-Peña MC, Mackie K, Walker JM. 1998. Immunohistochemical distribution of cannabinoid CB1 receptors in the rat central nervous system. Neuroscience 83: 393-411.

Vann SD, Aggleton JP, Maguire EA. 2009. What does the retrosplenial cortex do? Nature 10: 792-802.

Vogt BA, Absher JR, Bush G. 2000. Human retrosplenial cortex: where is it and is it involved in emotion? Trends Neurosci 23: 195-197.

Wang XY, Zhao M, Ghitza UE, Li YQ, Lu L. 2008. Stress impairs reconsolidation of drug memory via glucocorticoid receptors in the basolateral amygdala. J Neurosci 28: 5602-5610.

Wilson RI, Nicoll RA. 2001. Endogenous cannabinoids mediate retrograde signalling at hippocampal synapses. Nature 410: $588-592$.

Wyss JM, Sripanidkulchai K. 1984. The topography of the mesencephalic and pontine projections from the cingulate cortex of the rat. Brain Res 293: $1-15$.

Wyss JM, Van Groen T. 1992. Connections between the retrosplenial cortex and the hippocampal formation in the rat: a review. Hippocampus 2: $1-11$.

Received August 21, 2015; accepted in revised form September 29, 2015. 


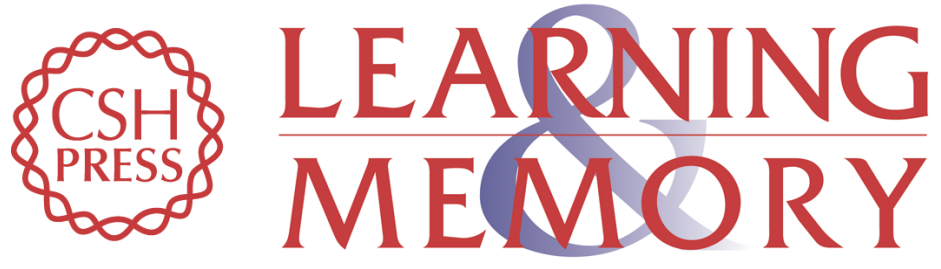

\section{The cannabinoid system in the retrosplenial cortex modulates fear memory consolidation, reconsolidation, and extinction}

Ricardo Marcelo Sachser, Ana Paula Crestani, Jorge Alberto Quillfeldt, et al.

Learn. Mem. 2015, 22:

Access the most recent version at doi:10.1101/lm.039891.115

References This article cites 53 articles, 17 of which can be accessed free at:

http://learnmem.cshlp.org/content/22/12/584.full.html\#ref-list-1

Creative This article is distributed exclusively by Cold Spring Harbor Laboratory Press for the

Commons

first 12 months after the full-issue publication date (see

License http://learnmem.cshlp.org/site/misc/terms.xhtml). After 12 months, it is available under a Creative Commons License (Attribution-NonCommercial 4.0 International), as described at http://creativecommons.org/licenses/by-nc/4.0/.

Email Alerting Receive free email alerts when new articles cite this article - sign up in the box at the Service top right corner of the article or click here. 